\title{
Amphetamine Regulates Gene Expression in Rat Striatum via Transcription Factor CREB
}

\author{
Christine Konradi, ${ }^{1,2}$ Rebecca L. Cole, ${ }^{1,3}$ Stephan Heckers, ${ }^{4}$ and Steven E. Hyman ${ }^{1,2}$ \\ 'Laboratory of Molecular and Developmental Neuroscience, Massachusetts General Hospital, Charlestown, \\ Massachusetts 02129, 'Department of Psychiatry, Massachusetts General Hospital and Harvard Medical School, Boston, \\ Massachusetts 02114, ${ }^{3}$ Program in Neuroscience, Harvard Medical School, Boston, Massachusetts 02115, and \\ ${ }^{4}$ Department of Medicine, Massachusetts General Hospital and Harvard Medical School, Boston, Massachusetts 02114
}

\begin{abstract}
Amphetamine is a psychostimulant drug of abuse that can produce long-lived changes in behavior including sensitization and dependence. The neural substrates of these drug effects remain unknown, but based on their prolonged time course, we hypothesize that they involve drug-induced alterations in gene expression. It has recently been demonstrated that amphetamine regulates the expression of several genes, including c-fos, via dopamine D1 receptors in rat striatum. Here we report that amphetamine induces phosphorylation of transcription factor CAMP response element binding protein (CREB) in rat striatum in vivo and that dopamine D1 receptor stimulation induces phosphorylation of CREB within specific complexes bound to CAMP regulatory elements. In addition, we show by antisense injection that CREB is necessary for $c$-fos induction by amphetamine in vivo. Since CREB has been implicated in the activation of a number of immediate-early genes as well as several neuropeptide genes, CREB phosphorylation may be an important early nuclear event mediating long-term consequences of amphetamine administration.
\end{abstract}

[Key words: psychostimulant, dopamine, antisense oligonucleotides, phosphorylation, CREB, c-fos, striatum]

The psychomotor stimulant amphetamine is among the most reinforcing drugs known. In humans acute psychostimulant administration produces euphoria, increased energy, decreased appetite, and decreased fatigue. At higher doses, psychostimulants may produce anxiety, irritability, and paranoid psychosis (Connell, 1958; Ellinwood, 1967; Gawin and Ellinwood, Jr., 1988). Chronic administration of amphetamine or cocaine can produce long-term behavioral changes (Klawans et al., 1978; Segal et al., 1980; Barnett et al., 1987). Unlike many other drugs that produce tachyphylaxis, repeated administration can produce progressively greater behavioral effects, an observation referred to as behavioral sensitization (Segal and Mandell, 1974; Sato et

Received Oct. 25, 1993; revised Mar. 16, 1994; accepted Mar. 24, 1994

We thank Barry Kosofsky for help with the evaluation of the microscopic slides, David Ginty and Michael Greenberg for the gift of the CREB and phosphoCREB antisera, and Alexia Pollack for advice with primary striatal cultures. This work was supported by PHS Grants DA07134 and MH44160 to S.H.; R.L.C. is supported by DA07282 to S.E.H.

Correspondence should be addressed to Christine Konradi, Ph.D., Laboratory of Molecular and Developmental Neuroscience, Massachusetts General Hospital, CNY2, Building 149, 13th Street, Charlestown, MA 02129.

Copyright (C) 1994 Society for Neuroscience $0270-6474 / 94 / 145623-12 \$ 05.00 / 0$ al., 1983; Robinson et al., 1988). Significantly, chronic psychostimulant administration can result in a profound state of dependence.

The predominant acute action of amphetamine in the brain is release of nonvesicular monoamines (Moore, 1977; Rutledge, 1978; Butcher et al., 1988; Knepper et al., 1988). The most convincingly established substrate for the reinforcing properties of amphetamine are facilitation of dopamine action in the ventral striatum including the nucleus accumbens (Phillips et al., 1975; Koob and Bloom, 1988; Kolta et al., 1989). While acute activation of "brain reward" circuitry may explain why certain drugs are self-administered, it does not, by itself, explain drug dependence. The nervous system generally responds to persistent drug-induced perturbations with compensatory adaptations. Because critical actions of amphetamine appear to involve the dopaminergic inputs into the striatum and nucleus accumbens, these structures have been important sites for the investigation of psychostimulant-induced neural plasticity.

The prolonged time course of both the initiation and maintenance of psychostimulant dependence has raised the question of whether long-term drug-induced alterations in gene expression play a critical role (Nestler, 1992; Hyman, 1993). Immediate-early genes (IEGs) and their protein products act to transduce extracellular signals into the regulation of genes involved in the differentiated function of neurons. Amphetamine has previously bcen shown to act via dopamine Dl receptors to induce expression of the IEG $c$-fos in striatum with a specific anatomic distribution (Robertson et al., 1989; Graybiel et al., 1990; Nguyen et al., 1992). It has also been shown to activate expression of the zinc finger transcription factor NGFI-A (zif268, egr 1) (Moratalla et al., 1992; Nguyen et al., 1992). Moreover, AP- 1 binding activity in striatum is induced after amphetamine administration (Nguyen et al., 1992).

Based on these observations, we studied events that may link amphetamine-mediated Dl receptor stimulation to induction of $c$-fos and other genes. D1 receptors activate the cAMP pathway and therefore cAMP-dependent protein kinase (PKA; Kebabian and Calne, 1979; Monsma et al., 1990). The predominant nuclear target of PKA involved in regulation of transcription appears to be the constitutively synthesized transcription factor cAMP response element binding protein (CREB) that is activated by $P K \Lambda$ via phosphorylation on its serine ${ }^{133}$ (Yamamoto et al., 1988; Gonzalez and Montminy, 1989). In transformed cell lines, cAMP response elements (CREs) and CREB protein have been shown to be involved in the transcriptional regulation 

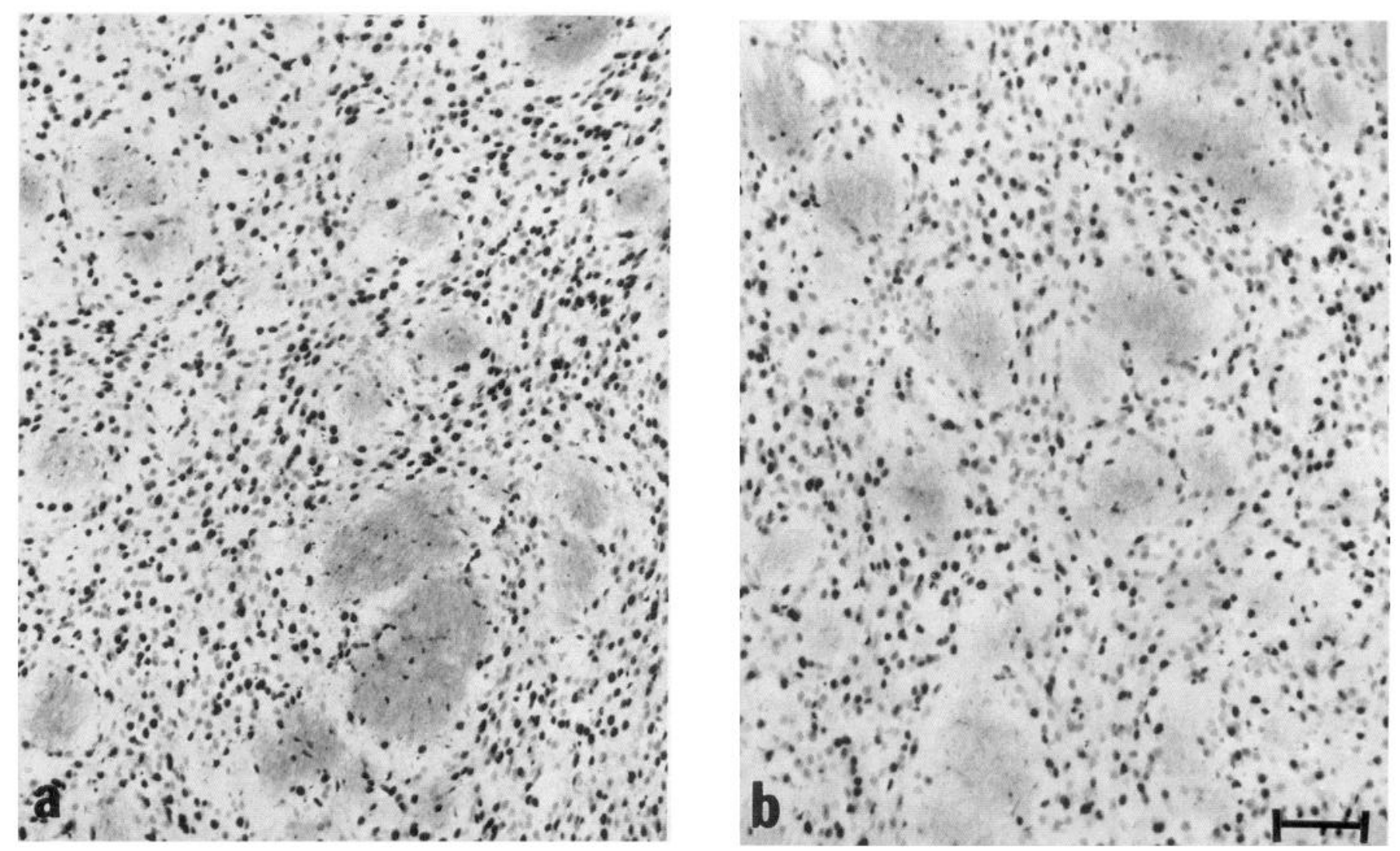

Figure 1. $a$ and $b$, CREB staining is similar in vehicle-treated $(a)$ and amphetamine-treated $(b)$ rats. No increase in staining intensity with the CREB antibody was observed in rat striatum $2 \mathrm{hr}$ after amphetamine $(b ; 4 \mathrm{mg} / \mathrm{kg}$, i.p.) treatment, as compared to saline $(a)$. $n=4 ;$ sections shown are coronal, at approximately $0.2 \mathrm{~mm}$ bregma. Scale bar, $100 \mu \mathrm{m}$.

of many genes, including IEGs such as $c$-fos (Sassone-Corsi et al., 1988; Sheng et al., 1990), and several neuropeptide genes, such as proenkephalin, somatostatin, and vasoactive intestinal polypeptide (Montminy and Bilezikjian, 1987; Fink et al., 1988; Hyman et al., 1988; Gonzalez and Montminy, 1989; Konradi et al., 1993). In the brain, CREB has been implicated in activation of the $c$-fos (Ginty et al., 1993) and proenkephalin genes (Konradi et al., 1993), but has not previously been shown to be required for such activation in vivo.

Here we demonstrate that amphetamine produces CREB phosphorylation in rat striatum in vivo via a D1 receptor-dependent mechanism. We also show that stimulation of D1 receptors on striatal neurons in primary culture induces phosphorylation of CREB on $\operatorname{Ser}^{133}$ (phosphoCREB) within specific protein-DNA complexes formed with cAMP response elements (CREs). Further, intrastriatal injection of antisense oligonucleotides directed against CREB inhibited induction of $c$-fos by amphetamine. CREB phosphorylation is likely an important step linking dopamine D1 receptor stimulation to long-term alterations in the properties of striatal neurons.

\section{Materials and Methods}

Antisera. The CREB and phosphoCREB (Ginty et al., 1993) polyclonal antisera were a gift from D. Ginty and M. Greenberg. The Fos antiserum (polyclonal; $\mathrm{Ab}-2$ ) and the c-Jun antiserum were purchased from Oncogene Science (Uniondale, NY).

Drugs. $S(+)$-amphetamine sulfate was obtained from Research Biochemicals Inc. (Natick, MA) and administered by intraperitoneal injection.

Immunohistochemistry. Male Sprague-Dawley rats (200-250 gm) were used for all experiments. Animals were perfused under deep pentobarbital anesthesia with $100 \mathrm{ml}$ of $0.9 \%$ saline, followed by $300 \mathrm{ml}$ of $4 \%$ paraformaldehyde in phosphate-buffered saline (PBS). For phosphoCREB experiments, preperfusion with saline was omitted. Brains were immersed in $30 \%$ sucrose for $24 \mathrm{hr}$ and $40 \mu \mathrm{M}$ sections were cut on a freezing microtome. All primary antisera were used at a dilution of $1: 1000$ and incubated with tissue slices overnight at $4^{\circ} \mathrm{C}$. The protocol used for subsequent steps was according to Vectastain Elite ABC kit (Vector Labs, Burlingame, CA); sections were developed with 3,3'-diaminobenzidine (Sigma). A different blocking solution was used for phosphoCREB antiserum (3\% bovine serum albumin, RIA grade, Sig$\mathrm{ma}$; $0.3 \%$ Triton X-100; and $50 \mathrm{~mm} \mathrm{NaF}$ in PBS).

Electrophoretic mobility-shift assays. For brain tissue experiments, striata, including the nucleus accumbens, were dissected and quickly

\footnotetext{
Figure 2. $a-d$, PhosphoCREB staining is increased in amphetamine-treated rats in a dopamine D1 receptor-dependent manner. Rats were treated intraperitoneally with saline $(a)$ or amphetamine $(4 \mathrm{mg} / \mathrm{kg} ; b)$ and perfused $15 \mathrm{~min}$ later. An increase in phosphoCREB immunoreactivity can be observed. Treatment with SCH23390 $(1 \mathrm{mg} / \mathrm{kg})$ alone, $30 \mathrm{~min}$ before perfusion, had no effect $(c)$. However, pretreatment with SCH23390 inhibited CREB phosphorylation in response to amphetamine $(d)$. SCH 23390 was given $30 \mathrm{~min}$ before perfusion; amphetamine $(4 \mathrm{mg} / \mathrm{kg}) 15 \mathrm{~min}$ before perfusion. $n=4$ for $a$ and $b, n=2$ for $c$ and $d$. Sections shown are coronal, around $0.2 \mathrm{~mm}$ bregma. Scale bar, $100 \mu \mathrm{m}$.
} 

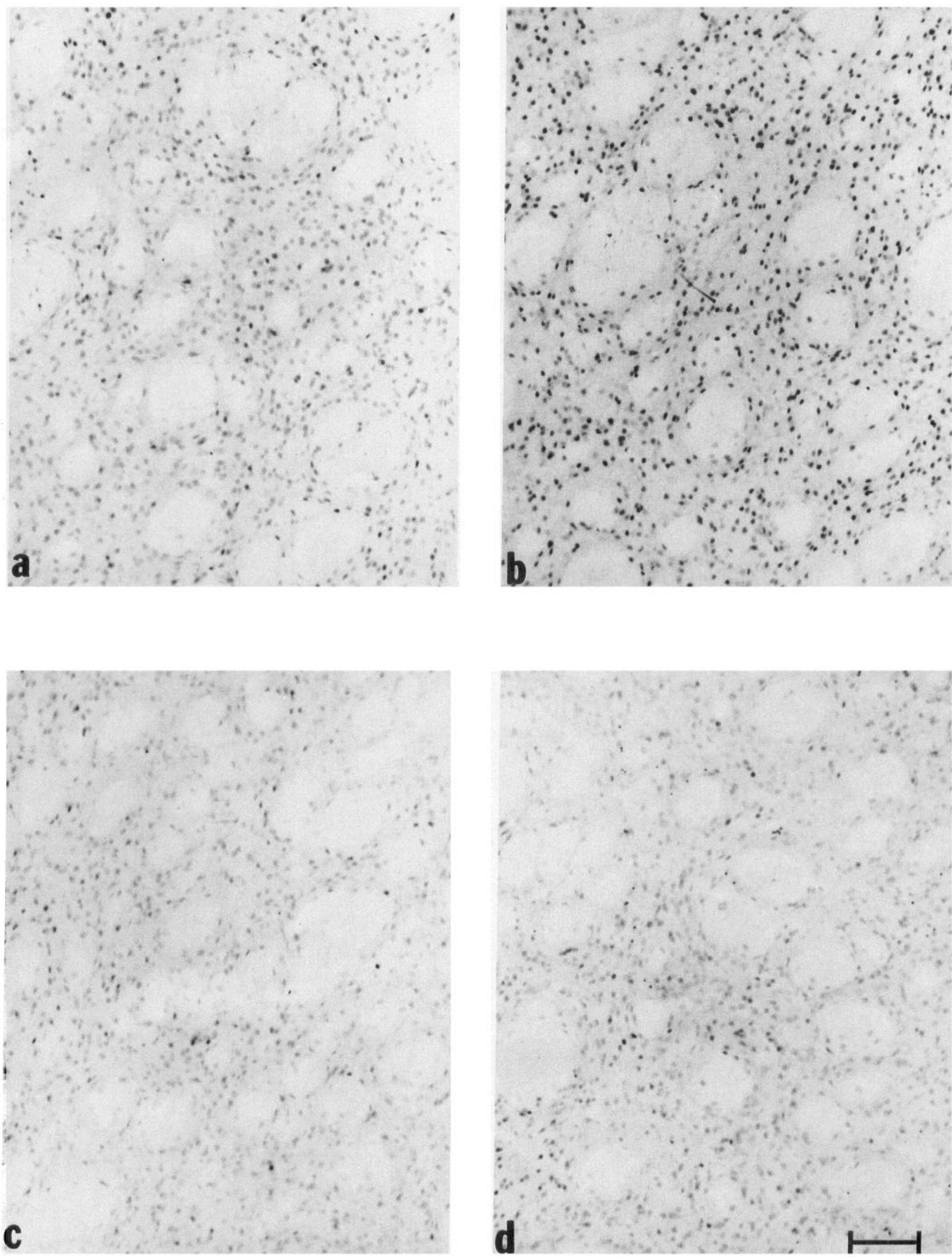
CaRE

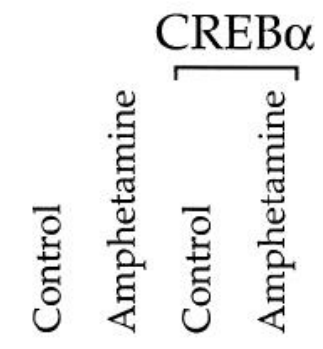

Figure 3. Electrophoretic mobility shift with the CaRE and ATF sites in the absence and presence of the CREB antiserum. Rats treated with saline or amphetamine $(4 \mathrm{mg} / \mathrm{kg})$ were killed 2 $\mathrm{hr}$ later. The resulting striatal extracts were incubated with the CaRE and ATF oligonucleotides with or without a specific CREB antiserum and subjected to electrophoresis. No difference in intensity of the shifted bands can be observed between saline- and amphetamine-treated rats. The CREB antiserum (CREB $\alpha$ lanes) disrupts and partly supershifts the specific complexes bound to the CaRE or ATF elements independently of treatment, while a Fos antiserum had no effect (data not shown). The additional band seen between the specific and the supershifted band in the CREB $\alpha$ lanes is a nonspecific serum band, as determined by preimmune-serum control experiments (Konradi et al., 1993). $n=3$.

\section{ATF}

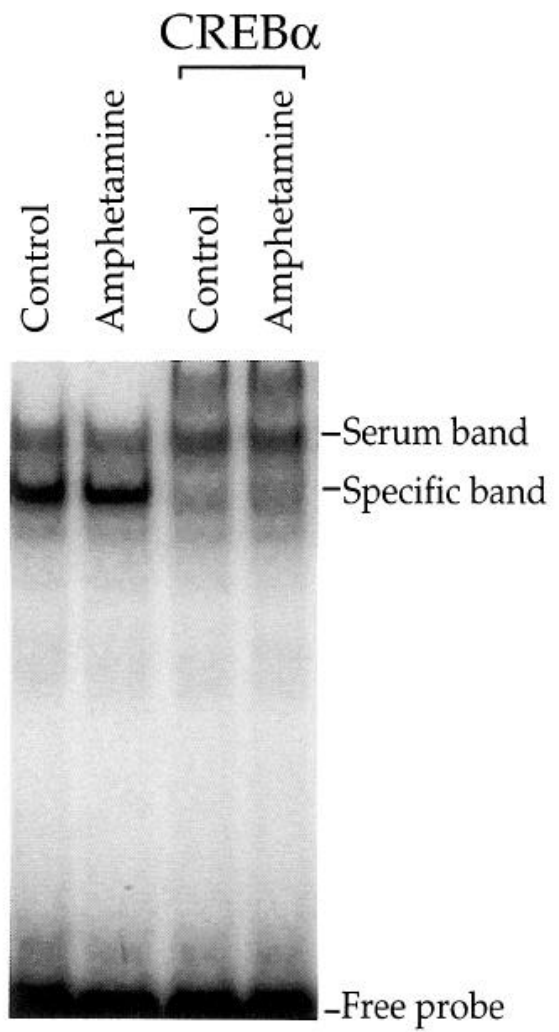

frozen on dry ice. Whole-cell extracts were prepared by sonicating the striata in sonication buffer ( $20 \mathrm{~mm}$ HEPES, $25 \%$ glycerol, $0.5 \mathrm{M} \mathrm{KCl}$, $1.5 \mathrm{~mm} \mathrm{MgCl}_{2}, 0.4 \mathrm{~mm}$ EDTA, $5 \mathrm{~mm}$ DTT, $1 \mathrm{~mm}$ EGTA, $0.5 \mathrm{~mm}$ PMSF) and centrifuging for $10 \mathrm{~min}$ at $14,000 \times g$ and $4^{\circ} \mathrm{C}$. The pellet was discarded and the supernatant used for electrophoretic mobilityshift assays.

For striatal culture experiments, media were aspirated and plates frozen on liquid nitrogen. Cells were scraped in $200 \mu \mathrm{l}$ of sonication buffer (as above) and sonicated for $5 \mathrm{sec}$. Sonication buffer used for phosphoCREB experiments also contained $1 \mathrm{~mm} \mathrm{NaF}$ and $5 \mu \mathrm{M}$ microcystin (Calbiochem, San Diego,CA). After centrifuging for $10 \mathrm{~min}$ at $14,000 \times g$ and $4^{\circ} \mathrm{C}$, the pellet was discarded and the supernatant used for electrophoretic mobility-shift assays.

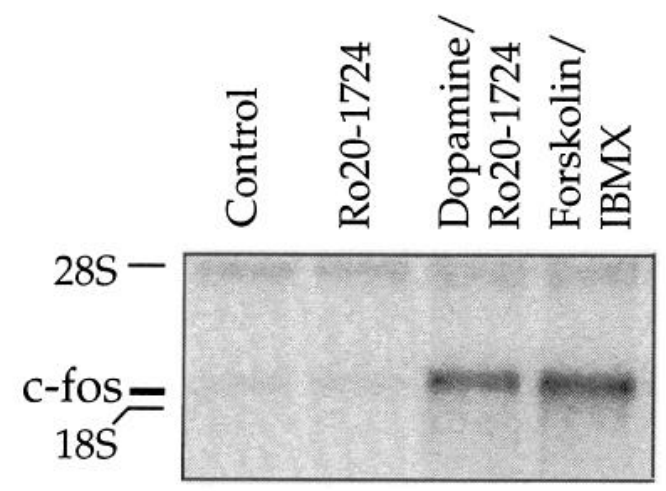

Figure 4. Dopamine and cAMP formation induce $c$-fos mRNA in primary striatal cultures. By Northern analysis with a $c$-fos riboprobe, induction is seen $30 \mathrm{~min}$ after dopamine $(50 \mu \mathrm{M}) / \operatorname{Ro} 20-1724(50 \mu \mathrm{M})$ or receptor-independent stimulation of the cAMP pathway by forskolin $(10 \mu \mathrm{M}) / \mathrm{IBMX}(500 \mu \mathrm{M})$. Ro20-1724 had no independent effect. $n=4$.
For binding, $4 \mu \mathrm{l}$ of either lysate was incubated on ice for $10 \mathrm{~min}$ in binding buffer ( $15 \mu \mathrm{l}$ total volume) containing $10 \mathrm{~mm}$ HEPES ( $\mathrm{pH} 7.9)$, $10 \%$ glycerol, $0.1 \mathrm{~mm}$ EDTA, $8 \mathrm{~mm} \mathrm{MgCl}_{2}, 2 \mathrm{~mm}$ DTT, and $10 \mathrm{mg} / \mathrm{ml}$ poly dI-dC) at $4^{\circ} \mathrm{C}$ with or without unlabeled competitor. In the presence of antisera, preincubation was extended to $15 \mathrm{~min}$. After preincubation, $1 \mathrm{ng}$ of ${ }^{32} \mathrm{P}$-labeled double-stranded oligonucleotide was added. Samples were incubated for $10 \mathrm{~min}$ at $23^{\circ} \mathrm{C}$ and then electrophoresed through a $4 \%$ nondenaturing polyacrylamide gel (30:1 acrylamide:bisacrylamide) in $0.25 \times$ TBE (Sambrook et al., 1989) and 3\% glycerol. The gel was subsequently dried and autoradiographed.

Oligonucleotides were synthesized with partial Bam $\mathrm{Hl}$ sites and annealed in the presence of $20 \mathrm{mM} \mathrm{NaPO}_{4}, 1 \mathrm{~mm}$ EDTA, and $100 \mathrm{~mm}$ $\mathrm{KCl}$. The partial Bam $\mathrm{H} 1$ sites of the double-stranded oligonucleotides were then filled in with ${ }^{32} \mathrm{P}$-labeled dCTP and unlabeled dATP, dGTP, and dTTP. Sequence of oligonucleotides used in electrophoretic mobility-shift assays was as follows (the partial Bam $\mathrm{Hl}$ site is shown in italic, core consensus sequences in boldface): activating transcription factor (ATF), 5' GATCGCTGACGTCAGGG 3' (Hoeffler et al., 1988; Hai et al., 1989); c-fos calcium response element (CaRE) site, 5'GATCCCCGTGACGTTTACA 3' (Sheng et al., 1990); AP-1 (derived from the human metallothionein promoter), $5^{\prime}$ GATCCGCGTGACTCAGCGC 3'; AP-1 (from the human substance $P$ promotor), $5^{\prime} G A T$ CAGCATGAGTCACTTC 3' (Konradi et al., 1993); and proenkephalin AP-4, 5'GATC GTCAGCTGCAGGG 3' (Comb et al., 1988).

Phosphorothioate oligonucleotides and intrastriatal injections. The following oligonucleotide sequences were used: CREB antisense, 5'TGGTCATCTAGTCACCGGTG3'; CREB sense, 5'CACCGGTGACTAGATGACCA3'; $c$-fos antisense, 5'CATCATGGTCGTGGTTTGGG3'; and $c$-fos sense, 5'CCCAAACCACGACCATGATG3'.

One microliter of a $2.5 \mathrm{~mm}$ solution of phosphorothioate oligonucleotide (Midland Co.) was infused into the rat striatum (coordinates: anterior/posterior, $+0.5 ;$ medial/lateral, \pm 3.2 ; dorsal/ventral, -6.0 ) of anesthetized rats (pentobarbital, $65 \mu \mathrm{g} / \mathrm{gm}$ body weight) in a stereotaxic frame.

Primary striatal cultures. Striata were dissected out under a stereo microscope from 19-d-old Sprague-Dawley rat fetuses. Tissue was suspended in $2 \mathrm{ml}$ of media (DMEM/F1 2 from GIBCO-Bethesda Research 
A

CaRE
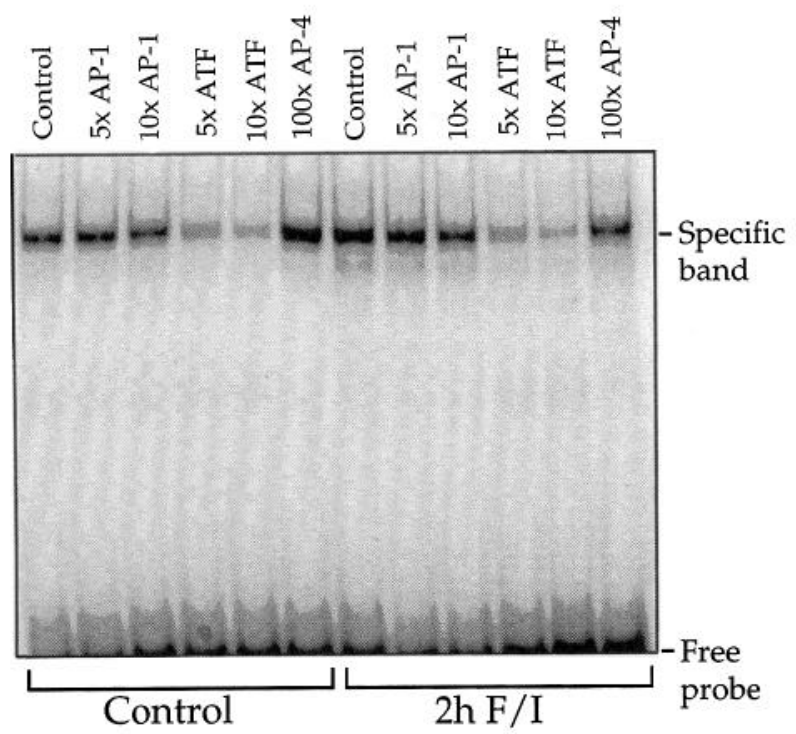

ATF
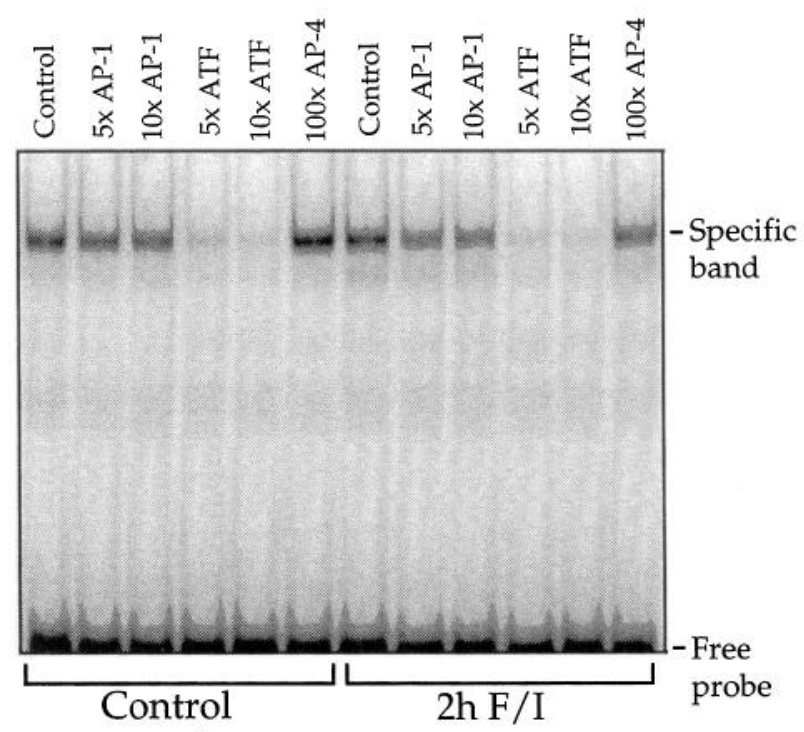

B

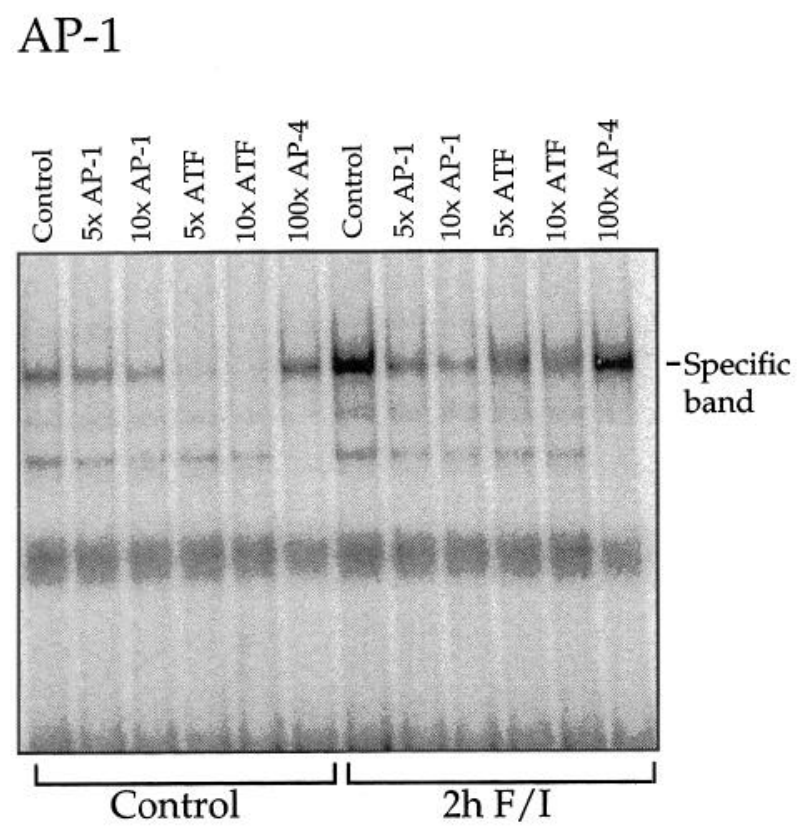

Figure 5. $A$ and $B$, Specificity of electrophoretic mobility-shift assay in primary striatal cultures. In untreated cultures, the unlabeled ATF oligonucleotide competes more potently against all three sites used (CaRE, $A T F$, and $A P-1$ from the substance P promoter) than does an AP-1 oligonucleotide (from the human metallothionein promoter). Two hours after addition of forskolin/IBMX $(F / I)$, binding to the AP-1 site is induced $(B)$ and the pattern of competition by AP-1 and ATF oligonucleotides is altered. This altered competition pattern is not observed with the labeled CaRE or ATF oligonucleotides $(A)$. An unrelated AP-4 site does not compete even at a 100 -fold molar excess. Control at top signifies no cold competitor; Control at bottom signifies no drug treatment. Numbers at top signify molar excess of cold competitor oligonucleotides. 


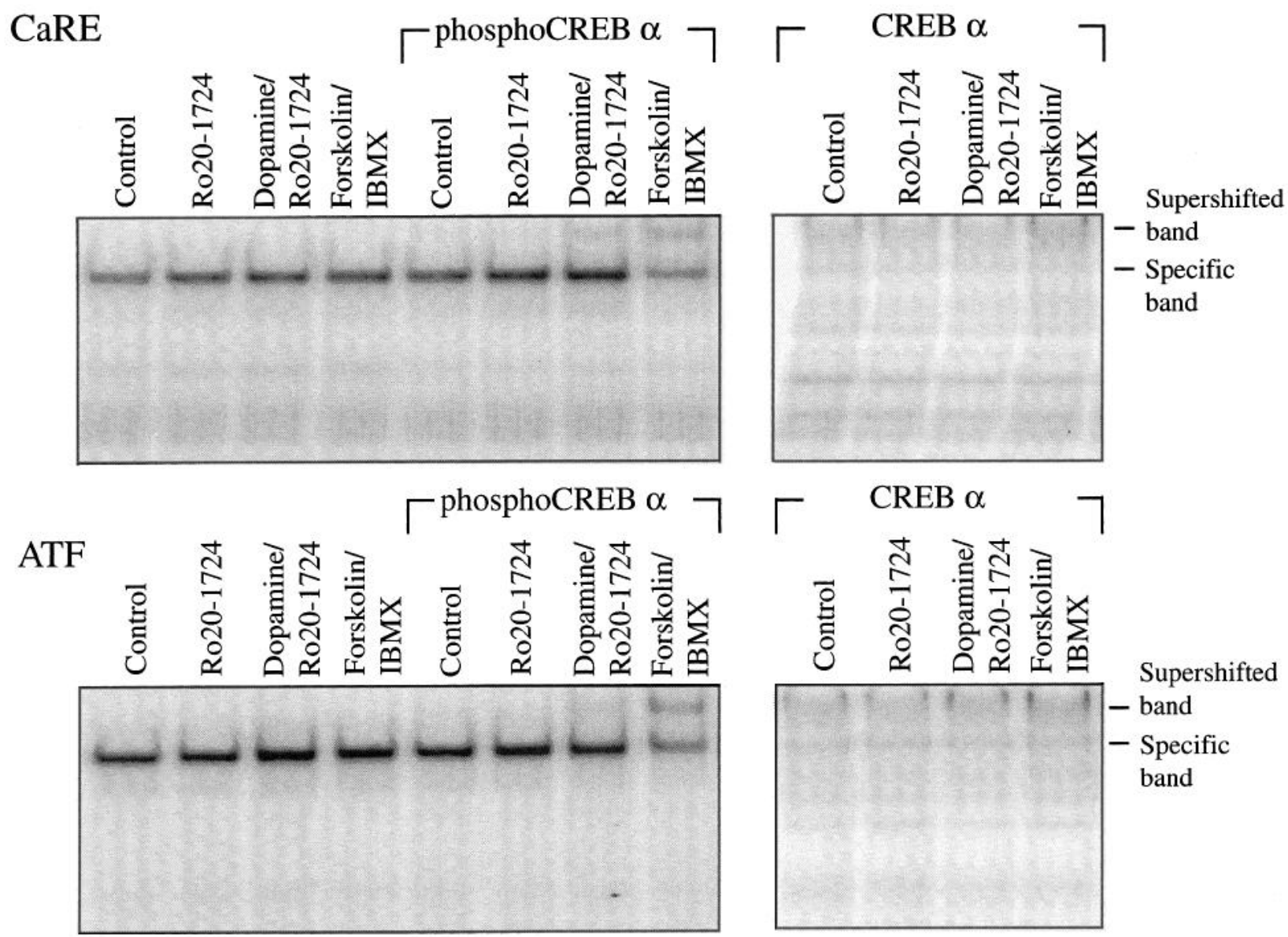

Figure 6. CREB and phosphorylated CREB bind to the CaRE and ATF sites. Striatal cultures were treated with dopamine ( $50 \mu \mathrm{M}) / \mathrm{Ro} 20-1724$ $(50 \mu \mathrm{M})$ or forskolin $(10 \mu \mathrm{m}) / \mathrm{IBMX}(500 \mu \mathrm{M})$. Ro20-1724 is a specific phosphodiesterase inhibitor and has no effect by itself (see also Fig. 4). Dopamine/Ro20-1724 and forskolin/IBMX cause an increase in CREB phosphorylation, which is reflected in an increased supershift with the phosphoCREB antiserum (phosphoCREB $\alpha$ ). Dopamine/Ro20-1724 targets only a subset of cells in the cultures, that is, only those neurons with dopamine receptors, and yields less phosphorylated CREB than does the receptor-independent forskolin/IBMX. The CREB antiserum is insensitive to phosphorylation status and shifts all lanes equally well (CREB $\alpha$ lanes). $n=5$.

Labs, Gaithersburg, MD, with the following supplements per liter of medium: $4.5 \mathrm{gm}$ of glucose, $1.5 \mathrm{ml}$ of penicillin-streptomycin liquid from GIBCO-Bethesda Research Labs, and 10\% Nu-serum 1 from Collaborative Biomedical Products, Bedford, MA) with $0.2 \%$ DNase. The tissue was mechanically dissociated with a fire-narrowed Pasteur pipette, and then centrifuged at $1000 \mathrm{rpm}$ for $5 \mathrm{~min}$. The medium was aspirated, and the cells were resuspended to $10^{6} \mathrm{cells} / \mathrm{ml}$ and plated in six-well plates (Costar, Cambridge, MA) at $2 \times 10^{6}$ cells/well. Plates were pretreated as follows: $2 \mathrm{ml}$ of a 1:500 diluted solution of polyethylenimine in 50 mm sodium borate $\mathrm{pH} 7.4$ was left on the plates overnight; next morning, plates were washed twice with PBS, left with medium for about $4 \mathrm{hr}$, and aspirated just prior to plating the cells.

Experiments were performed with cells $6-8 \mathrm{~d}$ in culture. At this time, the ratio of cells stained histochemically for neuron-specific enolase versus glial fibrillary acid protein was greater than 10:1. A small number of cells stained with neither antiserum. Drugs for treatment of cultures included dopamine (50 $\mu \mathrm{M})$; Ro20-1724 (50 $\mu \mathrm{M}$; Research Biochemicals Inc., Natick, MA), which is a selective inhibitor of cAMP phosphodiesterase; forskolin $(10 \mu \mathrm{M})$; 3-isobutyl-1-methylxanthine (IBMX) (500 $\mu \mathrm{M}$; Sigma, St. Louis, MO); and SCH23390 (100 $\mu \mathrm{M}$; Research Biochemicals Inc., Natick, MA), a selective inhibitor of dopamine D1 and D5 (also called D1a and Dib) receptors.

Northern blot analysis. Striatal cultures were washed twice with PBS on ice, scraped into a microcentrifuge tube, and centrifuged for $3 \mathrm{~min}$ at $14,000 \mathrm{rpm}$ and $4^{\circ} \mathrm{C}$; the supernatant aspirated, and the cells were lysed in $500 \mu \mathrm{l}$ of lysis buffer ( $50 \mathrm{~mm}$ Tris, pH $8.0,100 \mathrm{~mm} \mathrm{NaCl}, 5$ mм $\mathrm{MgCl}_{2}, 0.5 \%$ NP40). After a $5 \mathrm{~min}$ incubation on ice, cells were centrifuged for $2 \mathrm{~min}$ at $14,000 \mathrm{rpm}$ and $4^{\circ} \mathrm{C}$, the supernatant transferred, and SDS added to a $0.2 \%$ final concentration. Cells were ex tracted twice with phenol-chloroform, followed by a chloroform extraction and ethanol precipitation. RNA was size separated on a $1.2 \%$ denaturing agarose gel ( $1 \mathrm{~m}$ paraformaldehyde) in MOPS buffer (20 mM MOPS, pH 7.0, 5 mm sodium acetate, 1 mм EDTA), electroblotted onto a nylon membrane, and hybridized with a $c$-fos riboprobe (Riboprobe system, Promega, Madison, WI).

\section{Results}

$S(+)$-amphetamine sulfate $(4 \mathrm{mg} / \mathrm{kg})$ induced Fos-like immunoreactivity in striatum $2 \mathrm{hr}$ after drug administration (not shown), as previously reported (Graybiel et al., 1990; Ngyuen et al., 1992). It had no effect on levels of CREB-like immunoreactivity that appeared to be present in all cells under both basal and stimulated conditions (Fig. 1). However, using an antiserum that specifically detects CREB phosphorylated on $\mathrm{Ser}^{133}$ (Ginty et al., 1993), amphetamine $(4 \mathrm{mg} / \mathrm{kg}$ ) dramatically induced CREB phosphorylation (phosphoCREB) in the striatum (Fig. 2a,b). Amphetamine-induced CREB phosphorylation was blocked by pretreatment with $\mathrm{SCH} 23390(1 \mathrm{mg} / \mathrm{kg})$, a dopamine D1/D5 receptor antagonist (Fig. $2 a-d$ ). Given the paucity of D5 receptors in striatum (Tiberi et al., 1991), it is likely that amphetamine-induced CREB phosphorylation is therefore dependent on D1 receptors.

Amphetamine and cocaine induction of $c$-fos mRNA and 

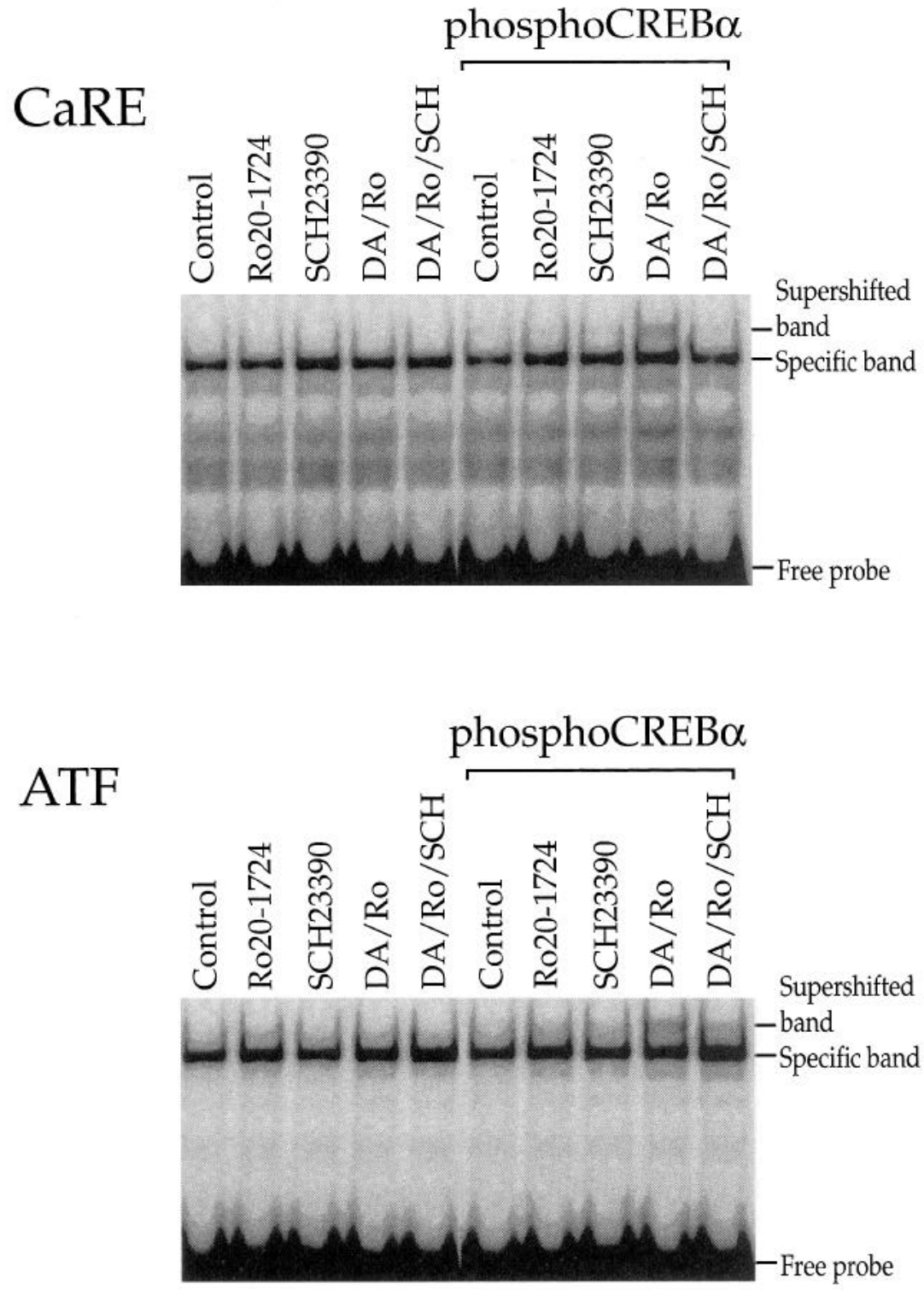

Figure 7. Dopamine induces CREB phosphorylation via D1 receptors in striatal cultures. Striatal cultures were treated for $15 \mathrm{~min}$ with Ro20-1724 (50 $\mu \mathrm{M})$, dopamine $(50 \mu \mathrm{M}) / \operatorname{Ro} 20-1724(50$ $\mu \mathrm{M})$, or SCH23390/Ro20-1724/dopamine. SCH23390 $(100 \mu \mathrm{M})$ was added $5 \mathrm{~min}$ before other drugs. No difference in binding intensity to the CaRE or ATF oligonucleotides was seen in the absence of antiserum. However, when supershifted with the phosphoCREB antiserum (phosphoCREB $\alpha$ ), an increased supershift, inhibited by $\mathrm{SCH} 23390$, was observed in the presence of dopamine/ Ro20-1724. $n=2$. protein are also inhibited by SCH23390 (Robertson et al., 1989; Graybiel et al., 1990; Young et al., 1991; Nguyen et al., 1992), and CREB has been shown to be upstream of $c$-fos induction in certain stimulus paradigms (Sheng et al., 1990; Ginty et al., 1993), acting via a cAMP- and $\mathrm{Ca}^{2+}$-inducible (CaRE) element (Sassone-Corsi et al., 1988; Sheng et al., 1990). We therefore examined the effects of amphetamine on the interaction between CREB protein and the $c$-fos CaRE element in striatal extracts using electrophoretic mobility-shift assays (Fig. 3). For comparison we also tested a palindromic consensus CREB binding site, designated ATF (Fig. 3). The specificity of protein complex formation with these oligonucleotides in striatal extracts has previously been demonstrated by cold competition (Konradi et al., 1993). Amphetamine ( $4 \mathrm{mg} / \mathrm{kg}$ ) caused no quantitative change in protein complexes bound to either the CaRE or ATF oligonucleotides in striatal extracts (Fig. 3), even though it induced binding (two- to fourfold) to an oligonucleotide containing a consensus AP-1 site (data not shown; Nguyen et al., 1992). Following either saline (control) or amphetamine administration, the specific complexes formed with the CaRE and ATF oligonucleotides appeared to contain CREB, as determined by incubating the specific protein-DNA complexes with an antiserum directed against CREB (Fig. 3).

Despite our ability to detect induction of CREB phosphorylation immunohistochemically in striatum following amphetamine, we were unable to observe induction of phosphoCREB DNA binding activity in extracts made from striatum (data not shown) possibly due to rapid dephosphorylation during the dissection. Rapid dephosphorylation is the likely mechanism because we have observed that suboptimal perfusion or cardiac arrest of animals, even when it occurred less than a minute before perfusion, yielded an absence of phosphoCREB immunoreactivity. The shortest time interval between death of an animal and quick freezing of the striatum was $2 \mathrm{~min}$. Therefore, we turned to striatal neurons in primary culture to investigate the effects of dopamine agonists on phosphoCREB DNA binding activity.

Since striatal neurons lack their dopaminergic inputs when placed in pure striatal cultures, indirect agonists such as amphetamine are not active. However, direct agonists, such as 

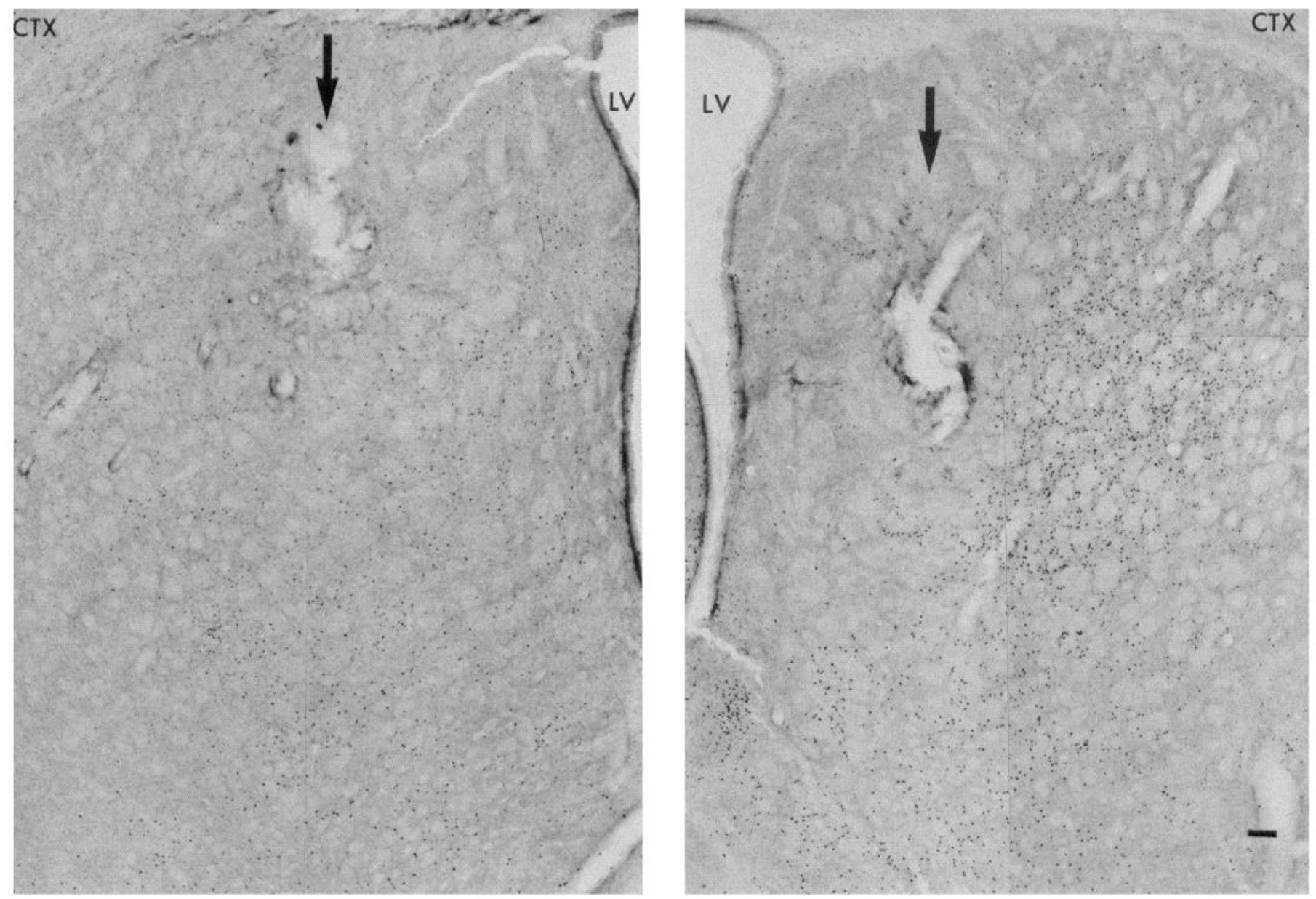

Figure 8. CREB antisense oligonucleotide injection into the striatum prevents Fos induction. Rats received a $4 \mathrm{mg} / \mathrm{kg}$ amphetamine injection (i.p.) $18 \mathrm{hr}$ after a bilateral intrastriatal injection of CREB antisense (left $)$ and sense (right) oligonucleotides. Rats were perfused $2 \mathrm{hr}$ after amphetamine injection and sections stained with Fos antiserum. Note reduced number of neurons staining for Fos on the antisense oligonucleotide side (left). Arrows point direction of needle tracks. $C T X$, cortex; $L V$, lateral ventricle. Scale bar, $100 \mu \mathrm{m}$.

dopamine itself, can be employed. In primary striatal cultures, dopamine $(50 \mu \mathrm{m})$ and the direct activator of adenylate cyclase, forskolin $(10 \mu \mathrm{m})$, together with cAMP phosphodiesterase inhibitors, both induced expression of $c$-fos mRNA (Fig. 4). Dopamine receptors are not known to be expressed on glia in striatum in vivo. However, to rule out the possibility that under our conditions of culture glia may mediate the effects of dopamine on gene expression, we compared our neuron-enriched cultures with glial-enriched cultures, which were grown in parallel. The glial-enriched cultures, produced by mechanically shaking off the neurons, contained less than $10 \%$ neurons. The induction of c-fos mRNA levels by dopamine $(50 \mu \mathrm{m})$ and Ro20-a724 $(50 \mu \mathrm{m})$ in neuron-enriched cultures was 40 -fold (Fig. 4), whereas the induction in the glial-enriched cultures was only 1.5 -fold (not shown). Thus, dopamine-induction of c-fos expression appears to occur in neurons rather than glia.

To investigate the effects of dopamine on the binding and phosphorylation status of CREB protein interacting with the $c$ - fos CaRE element, we performed electrophoretic mobility-shift analyses using cell extracts from primary cultures. We first characterized the specificity and the content of the complexes formed between these cell extracts and the CaRE, ATF, and AP-1 oligonucleotides as we have previously done for striatal extracts made directly from brain (Konradi et al., 1993). Using extracts from the primary cultures, the consensus CREB binding site (ATF) competed more avidly than the AP-1 oligonucleotide for proteins binding to the $\mathrm{ATF}$ and $\mathrm{CaRE}$ sites, while the unrelated AP-4 oligonucleotide in 100-fold molar excess did not compete at all (Fig. 5A). The labeled CaRE and ATF oligonucleotides showed no differences in competition patterns between control (untreated) cultures and cultures harvested $2 \mathrm{hr}$ after addition of forskolin and IBMX (Fig. 5A). In contrast, competition for binding to the labeled AP-1 site showed a marked difference between untreated cultures and cultures treated with forskolin and IBMX for $2 \mathrm{hr}$. Prior to forskolin/IBMX treatment, the ATF site was a stronger competitor than the AP-1 site, whereas

Figure 9. $a-d$, CREB antisense oligonucleotide injection into the striatum prevents Fos induction by reducing CREB protein levels: a higher magnification of Fos immunoreactivity after intrastriatal injection of CREB antisense $(a)$ and sense $(b)$ oligonucleotides (compare to Fig. 8). CREB immunoreactivity is shown on adjacent sections with CREB antisense $(c)$ and sense $(d)$ oligonucleotide injections. Arrows point to needle tracks. Scale bar, $100 \mu \mathrm{m}$. 

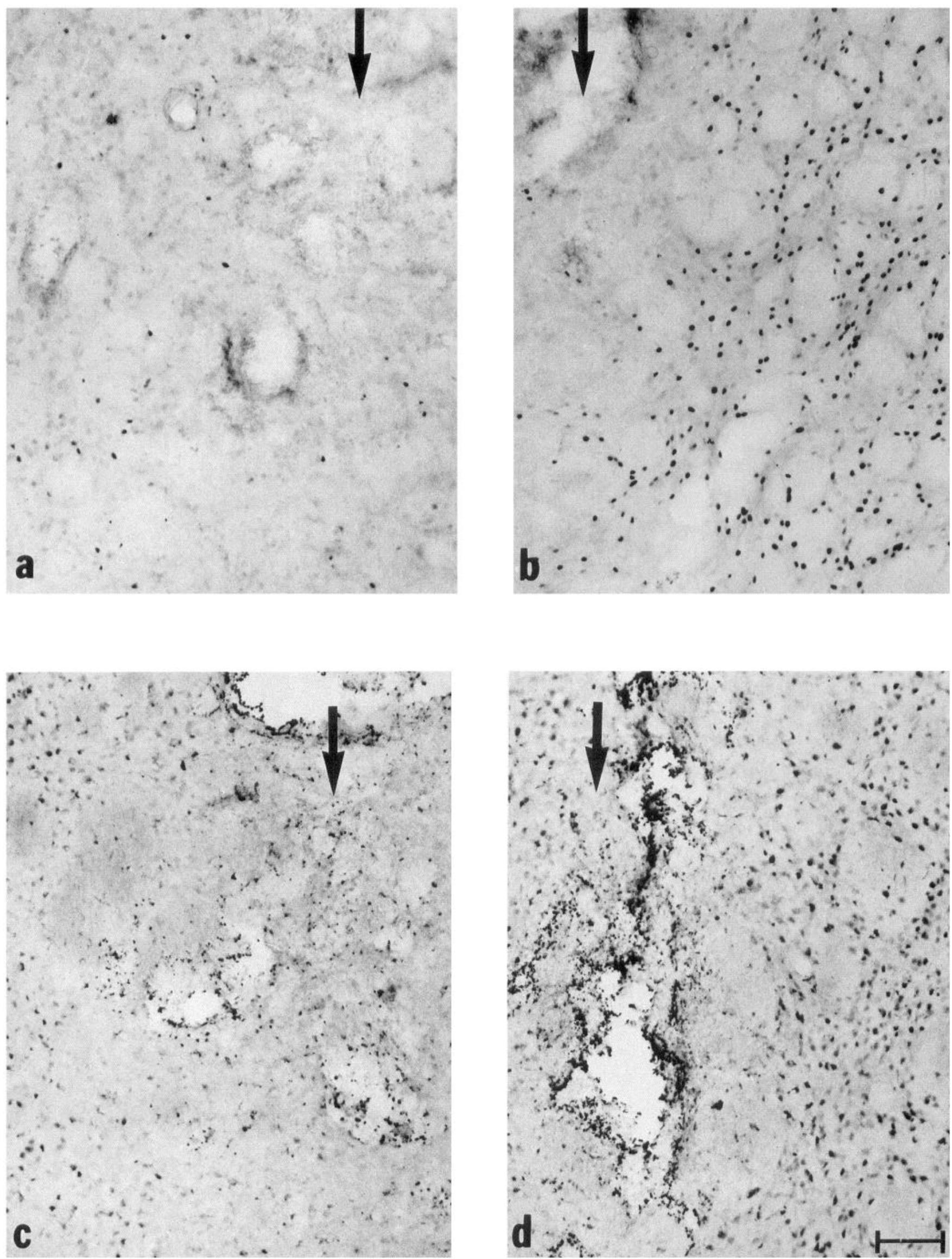
Table 1. Quantitation of Fos-positive nuclei following intrastriatal CREB antisense and sense oligonucleotide injection

\begin{tabular}{llll}
$\begin{array}{l}\text { Amphet- } \\
\text { amine } \\
\text { (i.p.) }\end{array}$ & \multicolumn{2}{l}{$\begin{array}{l}\text { Average number of } \\
\text { Fos-positive nuclei }\end{array}$} & $\begin{array}{l}\text { Average } \\
\text { decrease on } \\
\text { antisense side }\end{array}$ \\
\cline { 2 - 4 } & Antisense side & Sense side & $76.7 \pm 12.5 \%$ \\
$6 \mathrm{mg} / \mathrm{kg}$ & $771 \pm 207$ & $988 \pm 110$ & $6.2 \pm 4.7 \%$ \\
$4 \mathrm{mg} / \mathrm{kg}$ & $68 \pm 55$ & $969 \pm 149$ & $13.2 \pm 1.2 \%$ \\
$2 \mathrm{mg} / \mathrm{kg}$ & $60 \pm 8$ & $448 \pm 15$ &
\end{tabular}

Values represent the average from two cases each, \pm SEM. Fos-positive nuclei were counted with a graticule in an area of $1 \mathrm{~mm} \times 2 \mathrm{~mm}$, lateral of and adjacent to the needle track (at -0.3 bregma and $\pm 3.2-4.2$ medial-lateral coordinates: Paxinos and Watson, 1986). The first two consecutive animals of the $6 \mathrm{mg} / \mathrm{kg}$ and $4 \mathrm{mg} / \mathrm{kg}$ treatment groups were used for counting.

after treatment, the order of avidity of competition was reversed (Fig. 5B). This last observation differs from what we observe in extracts produced from striatum in vivo (Konradi et al., 1993, and data not shown), where AP-1 self-competition is always stronger than ATF site competition for proteins binding to a labeled AP-1 probe, under both unstimulated conditions and after amphetamine or haloperidol treatment. These data suggest that under conditions of culture, where cells are removed from both dopamine and glutamate innervation, levels of specific AP-1 proteins are very low in the unstimulated condition.

The composition of the specific complexes was then examined using antisera to disrupt or supershift specific shifted bands. A CREB antiserum supershifted specific bands formed with the CaRE and ATF oligonucleotides equally well, independently of treatment (Fig. 6) or time after treatment (in time courses up to $24 \mathrm{hr}$; data not shown). Dopamine or forskolin with phosphodiesterase inhibitors induced phosphoCREB in these complexes, as demonstrated by supershift with the specific antiserum (Fig. 6). The phosphoCREB supershift of dopamine/Ro20-1724 treated cells was inhibited by pretreatment with SCH23390 (Fig. 7), consistent with a D1-mediated mechanism.

Taken together, the findings in vivo and in culture are consistent with a role for CREB phosphorylation in activation of $c$-fos gene expression by dopamine in striatal neurons, and therefore in activation of $c$-fos gene expression by amphetamine in the striatum. To determine whether CREB is necessary for amphetamine induction of $c$-fos in vivo, sense and antisense phosphorothioate oligonucleotides directed against CREB were injected into opposite striata, and after a specific interval amphetamine $(2,4$, or $6 \mathrm{mg} / \mathrm{kg}, \mathrm{i} . \mathrm{p})$ was injected. Two hours after amphetamine administration, animals were killed and processed for Fos immunohistochemistry. In this design the striata from the two sides can be compared, rather than comparing across animals.

The interval between intrastriatal oligonucleotide injection and amphetamine administration that produced maximal suppression of $c$-fos expression by antisense (but not sense) oligonucleotides was determined by a time course with intervals of $18,24,46$, and $70 \mathrm{hr}$. At the end of each period animals received amphetamine and were, perfused $2 \mathrm{hr}$ later. Maximum suppression of Fos induction by amphetamine was observed when the interval between intrastriatal injection of antisense oligonucleotides against CREB mRNA and amphetamine injection was between 18 and $46 \mathrm{hr}$ (Figs. 8, 9). For comparison, a time course was also examined after injection of antisense oligonucleotides directed against $c$-fos mRNA itself. The maximum effect of suppression of Fos protein was observed when the interval between intrastriatal antisense (but not sense) oligonucleotide injection and amphetamine administration was 10 $\mathrm{hr}$. No difference between antisense and sense oligonucleotide injections was observed when the interval was $18 \mathrm{hr}$ (data not shown). When the interval was $24 \mathrm{hr}$, there appeared to be an increase in Fos protein on the side of the antisense injection, consistent with some type of rebound or sensitization phenomenon (data not shown). Suppression of Fos protein was not observed after injection of either sense CREB or sense $c$-fos oligonucleotides.

In all animals that received amphetamine ( $4 \mathrm{mg} / \mathrm{kg}$; i.p.) 18 hr after CREB antisense injection $(n=4)$, Fos staining was markedly reduced on the side of the antisense injection as compared to the sense control side (Figs. 8, 9; Table 1). Staining with CREB antiserum showed a reduction of CREB-like immunoreactivity on the side of the antisense oligonucleotide injection, but a complete suppression of CREB protein was not seen in any of the cases (Fig. 9). This could be due to the stability of preexisting CREB protein or the detection of other proteins with which the antiserum cross-reacts. However, the apparently partial reduction in CREB protein was enough to prevent amphetamine induction of Fos at $2 \mathrm{mg} / \mathrm{kg}(n=2)$ and $4 \mathrm{mg} / \mathrm{kg}(n$ $=4)$. Interestingly, a higher concentration of amphetamine (6 $\mathrm{mg} / \mathrm{kg} ; n=4$ ) overcame some of the block of Fos induction, consistent with the hypothesis that with a stronger stimulus there is enough CREB protein remaining to produce a response (Table 1). The dose-response and the time course data demonstrate that the injections have not rendered the tissue nonspecifically unresponsive to stimulation. In addition, there was no difference in c-Jun immunoreactivity between sides that received CREB sense (Fig. 10a) or CREB antisense (Fig. 10b) oligonucleotide.

\section{Discussion}

With the recognition that the long-term behavioral effects of psychostimulant administration may be explained by changes in intracellular signal transduction in dopamine-responsive systems, including activation of transcription factors, a substantial body of research has been produced examining induction of IEGs by amphetamine and cocaine (Robertson et al., 1989; Graybiel et al., 1990; Young et al., 1991; Hope et al., 1992; Moratalla et al., 1992; Nguyen et al., 1992). The purpose of the present study was to investigate in vivo what may be the earliest nuclear event in psychostimulant regulation of gene expression, phosphorylation of the transcription factor CREB. In addition to demonstrating that amphetamine produces CREB phosphorylation in striatum, and that this effect is dependent on D1 receptors, we examined dopamine-regulated interactions of CREB in striatal neurons with $c$-fos, one of its best characterized targets (Sassone-Corsi et al., 1988; Sheng et al., 1990). Fos protein is markedly increased in striatum after amphetamine administration, but no change in CREB protein is observed immunohistochemically. Small changes in CREB content per cell may not be detected by this method, but there were also no changes in the number of CREB-immunoreactive cells. These results are consistent with studies in cell lines, in which CREB is reported to be constitutively expressed and activated by phosphorylation on $\operatorname{Ser}^{133}$ (Gonzalez and Montminy, 1989). CREB binding to the CaRE regulatory element of the $c$-fos promoter (and the palindromic ATF site) was demonstrated in electrophoretic mobility-shift assays using both striatal (brain) extracts and extracts from primary striatal cultures. Consistent with our immunohistochemical data, no quantitative change in the spe- 

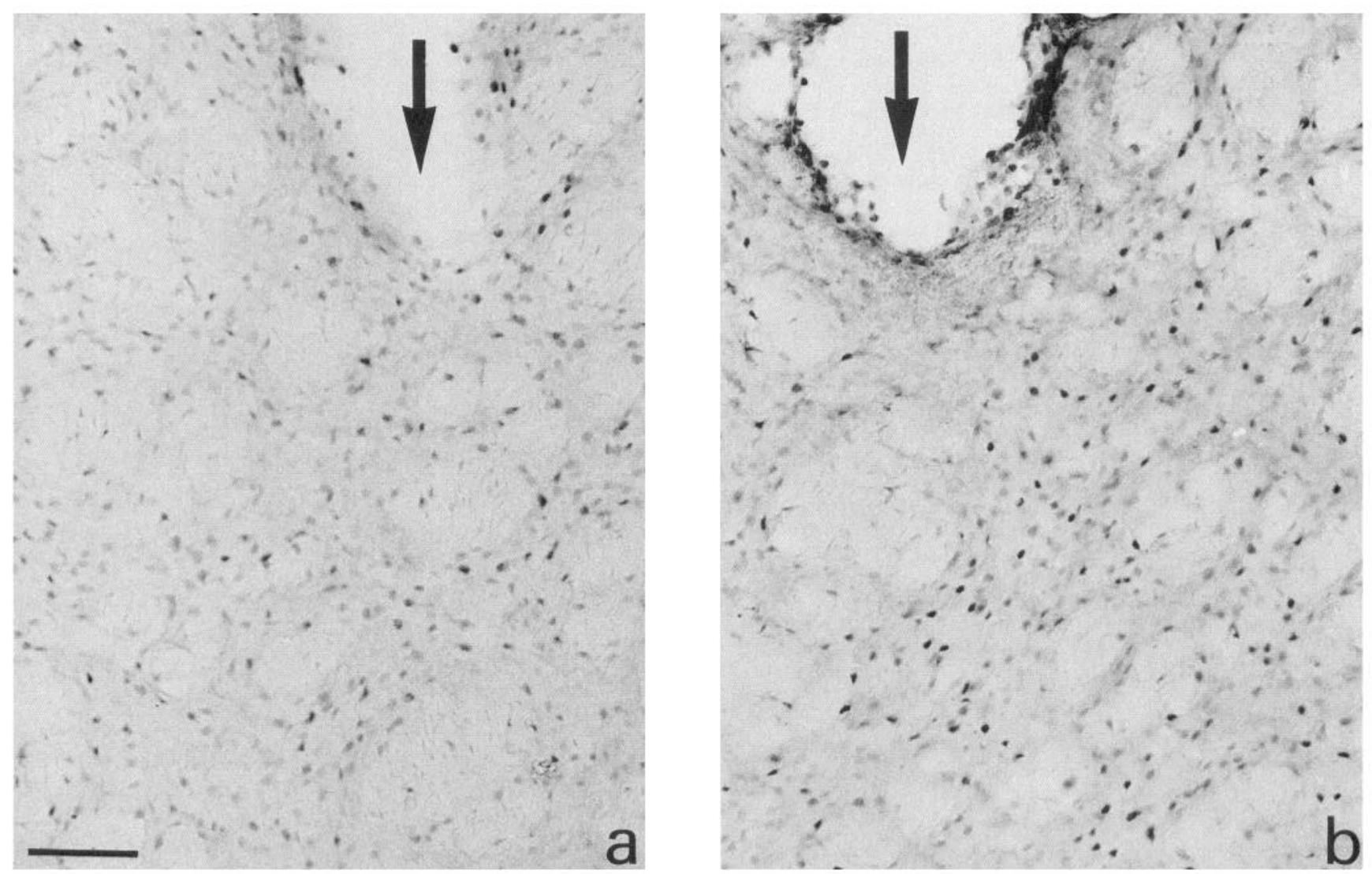

Figure 10. $a$ and $b$, CREB antisense oligonucleotide injection into the striatum does not affect c-Jun immunostaining: c-Jun immunoreactivity after intrastriatal injection of CREB sense $(a)$ and antisense $(b)$ oligonucleotides. Sections adjacent to those shown in Figures 8 and 9 . There is no difference seen in c-Jun immunoreactivity between sides. Arrows point to needle tracks. Scale bar, $100 \mu \mathrm{m}$.

cific CREB-containing complex is seen either in striatal extracts from amphetamine-treated rats compared with saline controls, or in striatal cultures treated with dopamine or forskolin compared with controls. In striatal cultures we demonstrate that dopamine and forskolin both induce Ser ${ }^{133}$ phosphorylation of CREB in specific complexes interacting with the CaRE and the ATF elements. This is followed temporally by an increase in expression of $c$-fos mRNA. Dopamine-induced CREB phosphorylation in these cultures is blocked by pretreatment with a D1/D5 receptor antagonist, as demonstrated by blockade of the induction of phosphoCREB in complexes binding to the CaRE and ATF oligonucleotides in electrophoretic mobility-shift assays. Finally, using antisense oligonucleotide injections we show that the amphetamine-induced $c$-fos expression is dependent upon CREB protein. Direct antisense injection into brain is a relatively new approach that is difficult to fully evaluate. Because we injected sense and antisense oligonucleotides into opposite striata in each animal, each antisense experiment had a withinanimal control. This design rules out animal-to-animal variation in drug response, and also makes it highly unlikely that the observed differences between sense and antisense injections could be due to uneven drug delivery. In our time course experiments we observed recovery of Fos induction, and even hyper-responsiveness in the longest time interval between CREB antisense injection and amphetamine administration. This is further evidence that the observed antisense effects result from specific inhibition of a signal transduction pathway and not from nonspecific toxicity or injury. Specificity was also shown by staining with a c-Jun antibody, which was not suppressed after CREB antisense oligonucleotide injection.

CREB appears to play a critical role in transducing activation of the cAMP system and additionally some of the effects of intracellular $\mathrm{Ca}^{2+}$ (Yamamoto et al., 1988; Sheng et al., 1990) into activation of gene expression. Amphetamine-induced phosphorylation of this nearly ubiquitously expressed transcription factor has far-reaching consequences for neurons in the dorsal and ventral (limbic) striatum as well as other brain regions innervated by monoaminergic neurons. Along with short-term chemical changes in the brain (Graybiel et al., 1990; $\mathrm{Li}$ et al., 1990; Trujillo et al., 1990; Hurd and Herkenham, 1992; Norman et al., 1993), amphetamine produces long-term changes with significant behavioral consequences that may, in part, reflect altered patterns of gene expression. Here we demonstrate that amphetamine produces specific phosphorylation of CREB and further demonstrate the dependence of one target gene, $c$ fos, on CREB. However, CREB interacts with a large number of genes including not only IEGs, but also neuropeptides such as somatostatin, vasoactive intestinal polypeptide, proenkephalin, and prodynorphin (Montminy and Bilezikjian, 1987; Fink et al., 1988; Montminy et al., 1990; Cole et al., 1993; Konradi et al., 1993), and a multiplicity of other genes. It is therefore likely that amphetamine-induced CREB phosphorylation has the potential to affect a large number of target genes in D1 dopamine receptor-containing neurons, and may be a critical early event in stimulant-induced regulation of gene expression in the striatum. 


\section{References}

Barnett JV, Segal DS, Kuczenski R (1987) Repeated amphetamine pretreatment alters responsiveness of striatal dopamine-stimulated adenylate cyclase to amphetamine induced desensitization. J Pharmacol Exp Ther 242:40-47.

Butcher SP, Fairbrother IS, Kelly JS, Arbuthnott GW (1988) Amphetamine-induced dopamine release in the rat striatum: an in vivo microdialysis study. J Neurochem 50:346-355.

Cole RL, Konradi C, Douglass J, Hyman SEH (1993) Mechanisms of prodynorphin regulation in striatal neurons. Soc Neurosci Abstr 35: 11

Comb M, Mermod N, Hyman SE, Pearlberg J, Ross ME, Goodman HM (1988) Proteins bound at adjacent DNA elements act synergistically to regulate human proenkephalin cAMP inducible transcription. EMBO J 7:3793-3805.

Connell PH (1958) Amphetamine psychosis. London: Chapman and Hill.

Ellinwood EH (1967) Amphetamine psychosis: I. Description of the individuals and processes. J Nerv Ment Dis 144:273-283.

Fink JS, Verhave M, Kasper S, Tsukada T, Mandel G, Goodman RH (1988) The CGTCA sequence motif is essential for biological activity of the vasoactive intestinal peptide gene cAMP-regulated enhancer. Proc Natl Acad Sci USA 85:6662-6666.

Gawin FH, Ellinwood EH Jr (1988) Cocaine and other stimulants. N Engl J Med 318:1173-1182.

Ginty DD, Kornhauser JM, Thompson MA, Bading II, Mayo KE, Takahashi JS, Greenberg ME (1993) Regulation of CREB phosphorylation in the suprachiasmatic nucleus by light and circadian clock. Science 260:238-241.

Gonzalez GA, Montminy MR (1989) Cyclic AMP stimulates somatostatin gene transcription by phosphorylation of CREB at serine 133. Cell 59:675-680.

Graybiel AM, Moratalla R, Robertson HA (1990) Amphetamine and cocaine induce drug specific activation of the c-fos gene in striosomematrix compartments and limbic subdivisions of the striatum. Proc Natl Acad Sci USA 87:6912-6916.

Hai T, Liu F, Coukos WJ, Green MR (1989) Transcription factor ATF cDNA clones: an extensive family of leucine zipper proteins able to selectively form DNA-binding heterodimers. Genes Dev 3:2083-2090.

Hoeffler JP, Meyer TE, Yun Y, Jameson JL, IIabener JF (1988) Cyclic AMP-responsive DNA-binding protein: structure based on a cloned placental DNA. Science 242:1430-1433.

Hope B, Kosofsky B, Hyman SE, Nestler EJ (1992) Regulation of immediate early gene expression and AP-1 binding in the rat nucleus accumbens by chronic cocaine. Proc Natl Acad Sci USA 89:57645768.

Hurd YL, Herkenham M (1992) Influence of a single injection of cocaine, amphetamine or GBR 12909 on mRNA expression of striatal neuropeptides. Brain Res Mol Brain Res 16:97-104.

Hyman SE (1993) The molecular and cellular basis of addiction. Curr Opin Neurol Neurosurg 6:609-613.

Hyman SE, Comb M, Lin YS, Pearlberg J, Green MR, Goodman HM (1988) A common trans-acting factor is involved in transcriptional regulation of neurotransmitter genes by cyclic AMP. Mol Cell Biol 8:4225-4233.

Kebabian JW, Calne DB (1979) Multiple receptors for dopamine. Nature 277:93-96.

Klawans HL, Margolin DI, Dava N, Crosset P (1978) Supersensitivity to $d$-amphetamine and apomorphine-induced stereotyped behavior induced by chronic $d$-amphetamine administration. J Neurol Sci 25: 283-289.

Knepper SM, Grunewald GL, Rutledge CO (1988) Inhibition of norepinephrine transport into synaptic vesicles by amphetamine analogs. J Pharmacol Exp Ther 247:487-494.

Kolta MG, Shreve P, Uretsky NJ (1989) Effect of pretreatment with amphetamine on the interaction between amphetamine and dopamine neurons in the nucleus accumbens. Neuropharmacology 28:914.

Konradi C, Kobierski L, Nguyen TV, Heckers S, Hyman SE (1993) The cAMP-response-element-binding protein interacts, but Fos protein does not interact, with the proenkephalin enhancer in rat striatum. Proc Natl Acad Sci USA 90:7005-7009.

Koob GF, Bloom FE (1988) Cellular and molecular mechanisms of drug dependence. Science 242:715-723.
Li SJ, Jiang HK, Stachowiak MS, Hudson PM, Owyang V, Nanry K, Tilson HA, Hong JS (1990) Influence of nigrostriatal dopaminergic tone on the biosynthesis of dynorphin and enkephalin in rat striatum. Brain Res Mol Brain Res 8:219-225.

Monsma FJ, Mahan LC, Vittie LD, Gerfen CR, Sibley DR (1990) Molecular cloning and expression of a D1 dopamine receptor linked to adenylyl cyclase activation. Proc Natl Acad Sci USA 87:67236727.

Montminy M, Bilezikjian LM (1987) Binding of a nuclear protein to the cyclic-AMP response element of the somatostatin gene. Nature 328:175-178.

Montminy MR, Gonzalez GA, Yamamoto KK (1990) Regulation of cAMP-inducible genes by CREB. Trends Neurosci 13:184-188.

Moore KE (1977) The actions of amphetamine on neurotransmitters. A brief review. Biol Psychiatry 12:451-462.

Moratalla R, Robertson HA, Graybiel AM (1992) Dynamic regulation of NGFI-A (zif268, egr1) gene expression in the striatum. J Neurosci $12: 2609-2622$.

Nestler EJ (1992) Molecular mechanisms of drug addiction. J Neurosci 12:2439-2450.

Nguyen TV, Kosofsky BE, Birnbaum R, Cohen BM, Hyman SE (1992) Differential expression of c-Fos and Zif268 in rat striatum after haloperidol, clozapine, and amphetamine. Proc Natl Acad Sci USA 89: $4270-4274$.

Norman AB, Lu SY, Klug JM, Norgren RB (1993) Sensitization of $c$-fos expression in rat striatum following multiple challenges with $d$-amphetamine. Brain Res 603:125-128.

Paxinos G, Watson C (1986) The rat brain in stereotaxic coordinates, 2d ed. San Diego: Academic.

Phillips AG, Brooke SM, Fibiger HC (1975) Effects of amphetamine isomers and neuroleptics on self-stimulation from the nucleus accumbens and dorsal noradrenergic bundle. Brain Res 85:13-22.

Robertson HA, Peterson MR, Murphy K, Robertson GS (1989) D1dopamine receptor agonists selectively activate striatal c-fos independent of rotational behavior. Brain Res 503:346-349.

Robinson TE, Jurson PA, Bennett JA, Bentgen KM (1988) Persistent sensitization of dopamine neurotransmission in ventral striatum (nucleus accumbens) produced by prior experience with ( + )-amphetamine: a microdialysis study in freely moving rats. Brain Res 462 : 211-222.

Rutledge CO (1978) Effect of metabolic inhibitors and ouabain on amphetamine- and potassium-induced release of biogenic amines from isolated brain tissue. Biochem Pharmacol 27:511-516.

Sambrook J, Fritsch EF, Maniatis T (1989) Molecular cloning, 2d ed. Cold Spring Harbor, NY: Cold Spring Harbor Laboratory.

Sassone-Corsi P, Visvader J, Ferland L, Mellon PL, Verma IM (1988) Induction of proto-oncogene fos transcription through the adenylate cyclase pathway: characterization of a cAMP-responsive element. Genes Dev 2:1529-1538.

Sato M, Chen CC, Akiyama K, Otsuki S (1983) Acute exacerbation of paranoid psychotic state after long-term abstinence in patients with previous methamphetamine psychosis. Biol Psychiatry 18:429-440.

Segal DS, Mandell AJ (1974) Long-term administration of amphetamine: progressive augmentation of motor activity and stereotypy. Pharmacol Biochem Behav 2:249-255.

Segal DS, Weinberger SB, Cahill T, McCunney SJ (1980) Multiple daily amphetamine administration: behavioral and neurochemical alterations. Science 207:904-906.

Sheng M, McFadden G, Greenberg M (1990) Membrane depolarization and calcium induce c-fos transcription via phosphorylation of transcription factor CREB. Neuron 4:571-582.

Tiberi M, Jarvie KR, Silvia C, Falardeau P, Gingrich JA, Godinot N, Bertrand L, Yang-Feng TL, Fremeau RT Jr, Caron MC (1991) Cloning, molecular characterization, and chromosomal assignment of a gene encoding a second D1 dopamine receptor subtype: differential expression pattern in rat brain compared with the D1A receptor. Proc Natl Acad Sci USA 88:7491-7495.

Trujillo KA, Day R, Akil H (1990) Regulation of striatonigral prodynorphin peptides by dopaminergic agents. Brain Res 518:244-256.

Yamamoto KK, Gonzalez GA, Biggs WH III, Montminy MR (1988) Phosphorylation-induced binding and transcriptional efficiency of nuclear factor CREB. Nature 334:494-498.

Young ST, Porrino LJ, Iadarola MJ (1991) Cocaine induces striatal c-fos-immunoreactive proteins via dopaminergic D1 receptors. Proc Natl Acad Sci USA 88:1291-1295. 